Research article

\title{
Molecular characterization and antibiotic sensitivity testing of bacteria in blood cultures of Hepatitis B virus infected subjects
}

\author{
II Anibijuwon ${ }^{1}$, OC Ayanwale ${ }^{1}$ and OO Ayanda ${ }^{1}$ \\ Sri Lankan Journal of Infectious Diseases 2019 Vol.9 (1):68-78 \\ DOI: http://dx.doi.org/10.4038/sljid.v9i1.8228
}

\begin{abstract}
Introduction: Hepatitis B virus is one of the most common infections worldwide. Many infected people are at risk of developing liver complications. Screening for common pathogenic bacterial infections that could contribute to complications is important for early diagnosis and appropriate management.
\end{abstract}

Methods: A cross sectional study was carried out on subjects aged 20-75 years for a period of 6 months (November 2016 to April 2017). Blood cultures and HBsAg rapid tests were performed on all 122 blood samples collected in Ilorin Metropolis. The screening was carried out on 92 HbsAg positive patients who presented with fever, and 30 apparently healthy HbsAg positive donors from the blood bank.

Results: Of 92 symptomatic patients, 44 (47.8\%) had postive blood cultures and of the $30 \mathrm{HBV}$ positive blood donors, $9(30 \%)$ had positive blood cultures.

The prevalence of Escherichia coli, Staphylococcus aureus, Pseudomonas aeruginosa and Klebsiella pneumoniae in Hepatitis B positive subjects was $5.7 \%(n=7), 5.7 \%(n=7), 23.8 \%(n=29)$ and $9.8 \%(n=12)$ respectively. In the apparently healthy HbsAg positive blood donor group, only 9 samples showed positive bacterial growth of $P$. aeruginosa.

All the bacterial isolates were resistant to amoxycillin-clavulanic acid, erythromycin, ceftriaxone, ceftazidime, cefuroxime, and ciprofloxacin. On PCR, Nuc, Stx2, Pf and PSUE genes were demostrated in E. coli, $S$. aureus, $P$. aeruginosa and $K$. pneumoniae respectively.

Conclusion: This study showed a high percentage (45.1\%) of bacteraemia in HBV infection. Early screening and treatment of $\mathrm{HBV}$ infection and concomitant bacterial infection is recommended to prevent complications.

${ }^{1}$ Public Health Laboratory Unit, Department of Microbiology, Faculty of Life Sciences, University of Ilorin, P.M.B 1515, Ilorin, Kwara State, Nigeria.

Address for correspondence: Ibikunle Ibitayo Anibijuwon, Public Health Laboratory Unit, Department of Microbiology, Faculty of Life Sciences, University of Ilorin, P.M.B 1515, Ilorin, Kwara State, Nigeria Telephone: +2348036115296 Email: kunledoexploit@gmail.com; kunledoexploit@yahoo.com

(1D) https://orcid.org/0000-0003-0051-0396

Received 24 September 2018 and revised version accepted 2 March 2019

(c) (†)

use, distribution, and reproduction in any medium, provided the original author and source are credited 
Keywords: Hepatitis B, Liver, Antimicrobial susceptibility, Blood culture

\section{Introduction}

Many important questions still remain unanswered for many pathogen combinations. Co-infected individuals may be in worse health than those with single infections ${ }^{1}$ and may also pose the biggest risk of transmission to others. ${ }^{2}$ It is important to note that hepatitis is an occasional feature of the clinical symptoms induced by many agents of both living and non-living origin.

Hepatitis B virus (HBV) infection is an infection of major public health significance, being the $10^{\text {th }}$ leading cause of death globally. HBV infection accounts for 500,000 to 1.2 million deaths globally each year. ${ }^{3} \mathrm{HBV}$ infection can cause acute hepatitis, acute liver failure, chronic hepatitis, or can cause an asymptomatic infection and approximately 15-40\% of infected patients will develop cirrhosis, liver failure or hepatocellular carcinoma. ${ }^{4}$

Numerous studies have suggested that the genetic constitution of the host is a critical factor in determining the outcomes of HBV infection. Despite the effectiveness of the current vaccination policy, the prevalence of Hepatitis B infection remains high, and the burden for health services is considerable. ${ }^{5}$

Blood stream infection by Gram negative bacteria is a common complication in patients with cirrhosis. Patients with cirrhosis and ascites showed a higher susceptibility to bacterial infections because of their inadequate defence mechanisms. ${ }^{6}$ Very little is known about the correlation between HBV and different bacterial infections due to lack of diagnostic capability. The most common pathogenic agents, which enter the liver by vascular routes, are E. coli, K. pneumoniae, Salmonella Typhi, Proteus vulgaris, Streptococcus spp, and Staphylococcus spp, but anaerobes may also be present. ${ }^{7} S$. aureus, $P$. aeruginosa, and $K$. pneumoniae have been implicated in liver abscess. ${ }^{8} P$. aeruginosa is one of the most common causes of bacteraemia in liver transplant recipients. K. pneumoniae of high virulence (hvKP) has also been reported to lead to liver abscess in apparently healthy young adults. ${ }^{9}$ Among cases of pyogenic liver abscesses, Staphylococcus aureus has been established as the leading cause in most series. ${ }^{10}$ Uropathogenic E. coli (UPEC) has been reported to play a significant role in development of primary biliary cirrhosis (PBS). ${ }^{6}$

\section{Methods}

\section{Collection of samples and data}

The study protocol was reviewed by the University Ethics Review Board of the Faculty of Life Sciences, University of Ilorin and approval to carry out research was obtained from the Ethics Review Committee of the State Ministry of Health. All subjects gave written informed consent and were assured that all information was confidential. The target population (with or without fever) were confirmed as HBsAg positive at the Kwara State Civil Service Hospital, Specialist Hospital Sobi, General Hospital Ilorin and Blood Banks Ilorin, Nigeria from November 2016 to May 2017. They were above 18 years and the subjects' socio-demographic information were collected by administering a questionnaire. 
A total of $122 \mathrm{HBsAg}$ positive blood samples from patients attending Kwara State Civil Service Hospital, Sobi Specialist Hospital, Ilorin General Hospital, and the Blood Bank, Ilorin, Nigeria were confirmed between November 2016 - May 2017

Ninety-two (92) of the blood samples were collected from HBsAg positive patients of Kwara State Civil Service Hospital, Sobi Specialist Hospital and Ilorin General Hospital. Thirty blood samples (30) were collected from apparently healthy HBsAg positive donors from the blood bank.

Seven $\mathrm{ml}$ of venous blood was taken aseptically by needle and syringe with $2 \mathrm{ml}$ dispensed in $18 \mathrm{ml}$ of Thioglycollate medium and $5 \mathrm{ml}$ into a plain bottle. The samples in plain bottles were left at room temperature for 20-30 minutes to clot, centrifuged at 3000rpm for 5 minutes, and the resultant clear serum samples were packaged and transported to the laboratory in the Department of Microbiology, University of Ilorin for serological analysis of $\mathrm{HBV}$ using $\mathrm{HBsAg}$ and $\mathrm{HBcAg}$ (LifeSpan BioSciences, inc) rapid testing kits. All samples were tansported in a cold box at $+2{ }^{\circ} \mathrm{C}$ to $+8{ }^{\circ} \mathrm{C}$ and kept at $-20{ }^{\circ} \mathrm{C}$ in the laboratory for $18-24$ hours.

\section{Assay procedure for concomitant bacteria}

Thioglycollate media samples were incubated for 7 days with intermittent sub-culturing on Blood Agar at $37^{\circ} \mathrm{C}$ for $24 \mathrm{hrs}$ and examined for growth. Positive blood cultures were identified and subcultured on Blood Agar, MacConkey, Salmonella-Shigella Agar and Mannitol Salt Agar. Colonial and cellular morphology of the culture plates were observed, and necessary biochemical tests were carried out. ${ }^{11}$

\section{Antibiotics susceptibility test and ESBL screening}

This was done according to Clinical Laboratory Standard Institute (CLSI) Guidelines. ${ }^{12}$ Standard antimicrobial discs for Gram negative and Gram positive organisms was placed onto the surface of the inoculated agar plates accordingly and incubated for 24 hours. The zones of inhibition were measured and interpreted using the CLSI guidelines. ESBL screening was also performed by the disk synergy test. ${ }^{13}$

\section{DNA extraction and amplification of genes}

Crude method was used for DNA extraction of the bacterial isolates and polymerase chain reaction (PCR) was carried out to detect Universal genes Nuc, Stx2, Pf and PSUE in isolated S. aureus, E.coli, Klebsiella spp. and Pseudomonas spp. respectively using the primers and cycling parameters listed in Table 1. PCR amplification of genes was carried out for each gene singly using geneAmp PCR system 9700 thermal cycler (Applied Biosystems). All PCR assays were performed directly from bacterial suspensions obtained after rapid DNA extraction method. For the amplification master mix, an aliquot of $2 \mu \mathrm{l}$ of the bacterial suspension was added to $23 \mu \mathrm{l}$ of PCR mixture containing $50 \mathrm{mM} \mathrm{KCl}, 10 \mathrm{mM}$ Tris- $\mathrm{HCl}(\mathrm{pH} 8.6), 1.5 \mathrm{mM} \mathrm{MgCl} 2,5 \%$ glycerol, $0.08 \%$ NP-40, 0.05\% Tween-20, 0.2mM of each deoxynucleoside triphosphate (dATP, dTTP, dGTP, and 
$\mathrm{dCTP}), 10 \mu \mathrm{M}$ of respective primers and 25 units/ml of Taq DNA polymerase. All PCR assay runs incorporated a reagent control (without template DNA).

Table 1: Summary of the primers and PCR operating conditions

\begin{tabular}{|c|c|c|c|c|}
\hline Gene & Primer Sequence 5' $\rightarrow 3^{\prime}$ & Size & Cycle & Cycling Parameters \\
\hline$N u c$ & $\begin{array}{l}\text { GCGATTGATGGTGATACGGTT } \\
\text { AGCCAAGCCTTGACGAACTAAAGC }\end{array}$ & 274Bp & 35 & $\begin{array}{l}94^{\circ} \mathrm{C}-30 \mathrm{~s} ; 55^{\circ} \mathrm{C}-30 \mathrm{~s} ; 72^{\circ} \mathrm{C}-1 \\
\min \end{array}$ \\
\hline Stx 1 & $\begin{array}{l}\text { GTT ACG GGA AGG AAT CAG GGT } \\
\text { AAA CGC GGA AGG AAT CAG GGT }\end{array}$ & $300 \mathrm{Bp}$ & 35 & $\begin{array}{l}94{ }^{\circ} \mathrm{C}-30 \mathrm{~s} ; 60^{\circ} \mathrm{C}-30 \mathrm{~s} ; 72{ }^{\circ} \mathrm{C}-1 \\
\min \end{array}$ \\
\hline Psue & $\begin{array}{l}\text { AGCGTTCGTCCTGCACAAGT } \\
\text { TCCACCATGCTCAGGGAGAT }\end{array}$ & 98Bp & 35 & $\begin{array}{l}94{ }^{\circ} \mathrm{C}-30 \mathrm{~s} ; 58{ }^{\circ} \mathrm{C}-30 \mathrm{~s} ; 72{ }^{\circ} \mathrm{C}-1 \\
\min \end{array}$ \\
\hline$P f$ & $\begin{array}{l}\text { ATT TGA AGA GGT TGC AAA CGA T } \\
\text { TTC ACT CTG AAG TTT TCT TGT GTT C }\end{array}$ & $615 \mathrm{Bp}$ & 35 & $\begin{array}{l}94{ }^{\circ} \mathrm{C}-30 \mathrm{~s} ; 57^{\circ} \mathrm{C}-30 \mathrm{~s} ; 72^{\circ} \mathrm{C}-1 \\
\min ;\end{array}$ \\
\hline
\end{tabular}

\section{Agarose gel electrophoresis}

Agarose gel electrophoresis was carried out using 0.7\% agarose gel in 0.5X Tris borate EDTA buffer $(44.5 \mathrm{mM}$ Tris borate and $1 \mathrm{Mm}$ EDTA, $\mathrm{pH} 8.3)$. At the end of the run, the gel was transferred to a syngene gel documentation system (Syngene, UK) for agarose gel visualization using UV light. The DNA bands were then captured and visualized with a short wave ultraviolet trans illuminator and photographed using Syngene gel bio imaging system (UV trans-illuminator).

\section{Results}

Table 2 shows the distribution of bacterial isolates among the 122 samples collected. Twenty nine (23.8\%) of P. aeruginosa, 12 (9.8\%) of K. pneumoniae, 7 (5.7\%) of S. aureus, 7 (5.7\%) of E. coli made up the $55(45.1 \%)$ samples positive for bacterial infections. The prevalence of bacterial infections in patients with HBsAg was determined as $45.1 \%$.

Table 2: Age distribution of the prevalence of bacterial isolates among all $\mathrm{HBV}+\mathrm{ve}$ subjects

\begin{tabular}{lcccccc}
\hline $\begin{array}{l}\text { Age } \\
\text { (years) }\end{array}$ & $\begin{array}{c}\text { No } \\
\text { Examined }\end{array}$ & $\begin{array}{c}\text { Positive } \\
\text { samples }\end{array}$ & E. coli & P. aeruginosa & K. pneumoniae & S. aureus \\
\hline $18-27$ & 40 & 15 & 1 & 7 & 4 & 3 \\
$28-37$ & 19 & 11 & 2 & 7 & 1 & 1 \\
$38-47$ & 34 & 17 & 3 & 8 & 5 & 1 \\
$48-57$ & 18 & 10 & 1 & 6 & 2 & 1 \\
$58-67$ & 8 & 2 & 0 & 1 & 0 & 1 \\
$>68$ & 3 & 0 & 0 & 0 & 0 & 0 \\
Total & $\mathbf{1 2 2}$ & $\mathbf{5 5}$ & $\mathbf{7}$ & $\mathbf{2 9}$ & $\mathbf{1 2}$ & $\mathbf{7}$ \\
& $(\mathbf{1 0 0 \% )}$ & $\mathbf{( 4 5 . 1 \% )}$ & $\mathbf{( 5 . 7 \% )}$ & $\mathbf{( 2 3 . 8 \% )}$ & $\mathbf{( 9 . 8 \% )}$ & $\mathbf{( 5 . 7 \% )}$ \\
\hline
\end{tabular}


Table 3: Age distribution of the prevalence of bacterial isolates among HBsAg +ve patients

\begin{tabular}{lcccccc}
\hline $\begin{array}{l}\text { Age } \\
\text { (years) }\end{array}$ & No Examined & $\begin{array}{l}\text { Positive } \\
\text { Samples }\end{array}$ & E. coli & P. aeruginosa & K. pneumoniae & S. aureus \\
\hline $18-27$ & 32 & 13 & 1 & 5 & 4 & 3 \\
$28-37$ & 14 & 9 & 2 & 5 & 1 & 1 \\
$38-47$ & 27 & 13 & 3 & 6 & 4 & 0 \\
$48-57$ & 12 & 8 & 1 & 4 & 2 & 1 \\
$58-67$ & 5 & 1 & 0 & 0 & 0 & 1 \\
$>68$ & 2 & 0 & 0 & 0 & 0 & 0 \\
\hline Total & $\mathbf{9 2}$ & $\mathbf{4 4}$ & $\mathbf{7}$ & $\mathbf{2 0}$ & $\mathbf{1 1}$ & $\mathbf{6}$ \\
& $(\mathbf{1 0 0 \% )}$ & $\mathbf{( 4 7 . 8 \% )}$ & $\mathbf{( 7 . 6 \% )}$ & $\mathbf{( 2 1 . 7 \% )}$ & $\mathbf{( 1 2 . 0 \% )}$ & $(\mathbf{6 . 5 \%})$ \\
\hline
\end{tabular}

Table 4: Age distribution of the prevalence of bacterial isolates in healthy HBsAg +ve blood donors

\begin{tabular}{lcccccc}
\hline $\begin{array}{l}\text { Age } \\
\text { (years) }\end{array}$ & $\begin{array}{c}\text { No } \\
\text { Examined }\end{array}$ & $\begin{array}{c}\text { Positive } \\
\text { samples }\end{array}$ & E. coli & P. aeruginosa & K. pneumoniae & S. aureus \\
\hline $18-27$ & 8 & 2 & 0 & 2 & 0 & 0 \\
$28-37$ & 5 & 2 & 0 & 2 & 0 & 0 \\
$38-47$ & 7 & 2 & 0 & 2 & 0 & 0 \\
$48-57$ & 6 & 2 & 0 & 2 & 0 & 0 \\
$58-67$ & 3 & 1 & 0 & 1 & 0 & 0 \\
$>68$ & 1 & 0 & 0 & 0 & 0 & 0 \\
\hline Total & $\mathbf{3 0}$ & $\mathbf{9}$ & $\mathbf{0}$ & $\mathbf{9}$ & $\mathbf{0}$ & $\mathbf{0}$ \\
& $(\mathbf{1 0 0 \% )}$ & $\mathbf{( 3 0 . 0 \% )}$ & $\mathbf{( 0 . 0 \% )}$ & $\mathbf{( 3 0 . 0 \% )}$ & $\mathbf{( 0 . 0 \% )}$ & $(\mathbf{0 . 0 \%})$ \\
\hline
\end{tabular}

Forty-five males (36.9\%) and seventy-seven females $(63.1 \%)$ were enrolled in the study. Table 5 shows the gender distribution of the bacterial isolates

Table 5: Gender distribution of the prevalence of bacterial isolates among HBV +ve subjects

\begin{tabular}{|c|c|c|c|c|c|c|c|c|c|}
\hline \multirow[t]{2}{*}{ Gender } & \multirow[t]{2}{*}{ Samples } & \multicolumn{2}{|c|}{ E.coli } & \multicolumn{2}{|c|}{ S.aureus } & \multicolumn{2}{|c|}{ P.aeruginosa } & \multicolumn{2}{|c|}{ K. pneumonia } \\
\hline & & $\mathbf{n}$ & $\%$ & $\mathbf{n}$ & $\%$ & n & $\%$ & $\mathbf{n}$ & $\%$ \\
\hline Male & 45 & 3 & 6.7 & 4 & 8.9 & 13 & 28.9 & 3 & $6.7 \%$ \\
\hline Female & 77 & 4 & 8.9 & 3 & 3.9 & 16 & 6.67 & 9 & 6.6 \\
\hline Total & 122 & 7 & & 7 & & 29 & & 12 & \\
\hline
\end{tabular}

Figure 1 compares the distribution of bacterial isolates in the HBV positive patient group and HBV positive control group (blood donors). P. aeruginosa was the only isolate in the blood donor group. 


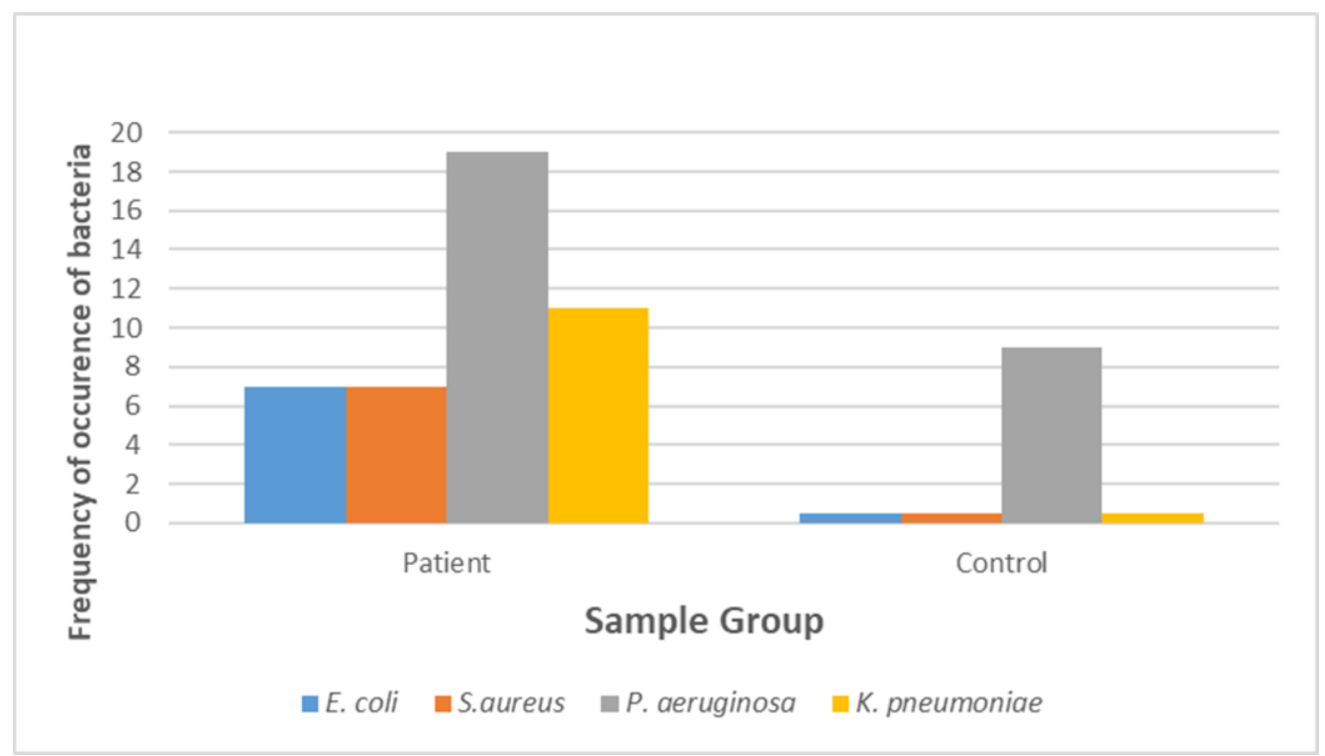

Figure 1: Distribution and comparison of bacterial isolates in $\mathrm{HBV}$ positive
subjects
(patients and control)

Antibiotic susceptibility testing of the $S$. aureus isolates showed multiple resistance to amoxycillinclavulanic acid (100\%), erythromicin (100\%), cloxacillicin (100\%), and ciprofloxacin (100\%). High sensitivity was also recorded with ofloxacin (85.7\%), and gentamicin (71.4\%).

As shown in Table 5, antibiotic susceptibility testing for the Gram negative bacteria shows high resistance to ceftazidime (100\%), cefuroxime (100\%), ciprofloxacin $(100 \%)$, amoxycillinclavulanic acid (97.9\%), and ceftriaxone(91.6\%). E. coli and K. pneumoniae showed high level susceptibility to ofloxacin (83.3\%), imipenem (83.3\%), gentamicin (75\%).

Phenotypic detection of extended spectrum $\beta$ lactamase (ESBL) production showed that 7 (24.1\%), $3(50 \%)$ and $3(25 \%)$ of the $P$. aeruginosa, E. coli and $K$. pneumoniae isolates were ESBL producers. 
Table 6: Antibiotic susceptibility of Gram negative isolates from patients

\begin{tabular}{|c|c|c|c|c|c|c|c|c|c|c|c|c|}
\hline \multirow[t]{2}{*}{ Antibiotic } & \multicolumn{4}{|c|}{$\begin{array}{c}\text { Pseudomonas aeruginosa } \\
n=29\end{array}$} & \multicolumn{4}{|c|}{$\begin{array}{c}\text { Klebsiella pneumoniae } \\
n=12\end{array}$} & \multicolumn{4}{|c|}{$\begin{array}{c}\text { Escherichia coli } \\
n=7\end{array}$} \\
\hline & $\mathrm{S}$ & $\%$ & $\mathrm{R}$ & $\%$ & $\mathrm{~S}$ & $\%$ & $\mathrm{R}$ & $\%$ & $\mathrm{~S}$ & $\%$ & $\mathrm{R}$ & $\%$ \\
\hline Augmentin $(30 \mu \mathrm{g})$ & \multicolumn{4}{|c|}{ Not tested } & 0 & 0 & 12 & 100 & 0 & 0 & 7 & 100 \\
\hline Ceftriaxone $(30 \mu \mathrm{g})$ & \multicolumn{4}{|c|}{ Not tested } & 0 & 0 & 12 & 100 & 0 & 0 & 7 & 100 \\
\hline Ceftazidime $(30 \mu \mathrm{g})$ & 0 & 0 & 29 & 100 & 0 & 0 & 12 & 100 & 0 & 0 & 7 & 100 \\
\hline Cefuroxime $(30 \mu \mathrm{g})$ & 0 & 0 & 29 & 100 & 5 & 41.6 & 7 & 58.3 & 5 & 71.4 & 2 & 28.6 \\
\hline Gentamicin $(10 \mu \mathrm{g})$ & 23 & 80 & 6 & 20 & 0 & 0 & 12 & 100 & 0 & 0 & 7 & 100 \\
\hline Ciprofloxacin $(10 \mu \mathrm{g})$ & 0 & 0 & 29 & 100 & 0 & 0 & 12 & 100 & 0 & 0 & 7 & 100 \\
\hline Imipenem $(10 \mu \mathrm{g})$ & 27 & 93.1 & 2 & $6 . .9$ & 4 & 33.3 & 8 & 66.7 & 4 & 57.1 & 3 & 42.9 \\
\hline ESBL positive & 22 & 75.9 & 7 & 24.1 & 9 & 75 & 3 & 25 & 4 & 57.1 & 3 & 42.9 \\
\hline
\end{tabular}

S-sensitive, R-resistance

Figures 2-5 demonstrate the relevant genes in the four species isolated from patients in the study.

$\begin{array}{llllllllll}17 & 18 & 30 & 6 & 70 & 81 & 83 & \text { +veC } & -v e C & \text { L }\end{array}$

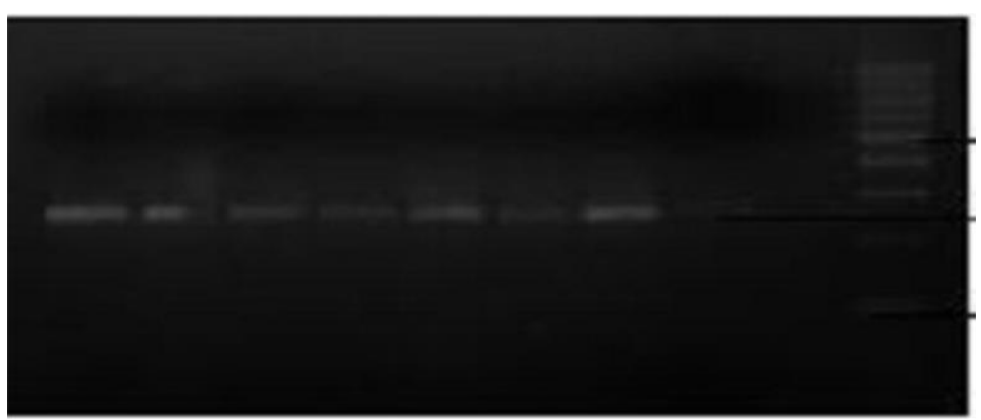

500Bp

274Bp

$100 \mathrm{Bp}$

+ve- C positive control; -veC- negative control; L - Ladder

Figure 2: PCR confirmed NUC gene in $S$. aureus isolates 


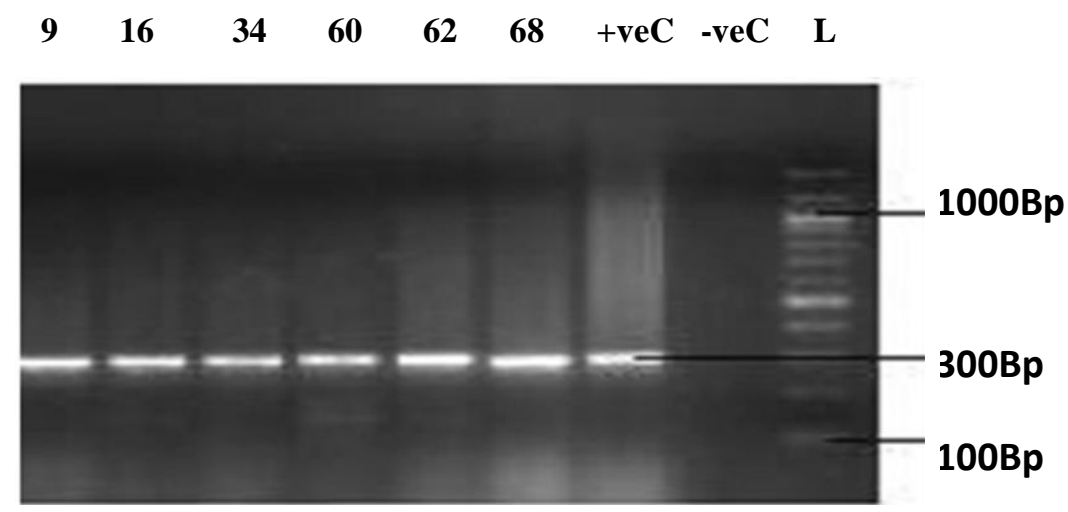

+ve C - positive control: -veC - negative control; $\mathrm{L}$ - ladder

Figure 3: PCR confirmed Stx2 gene in Escherichia coli isolates

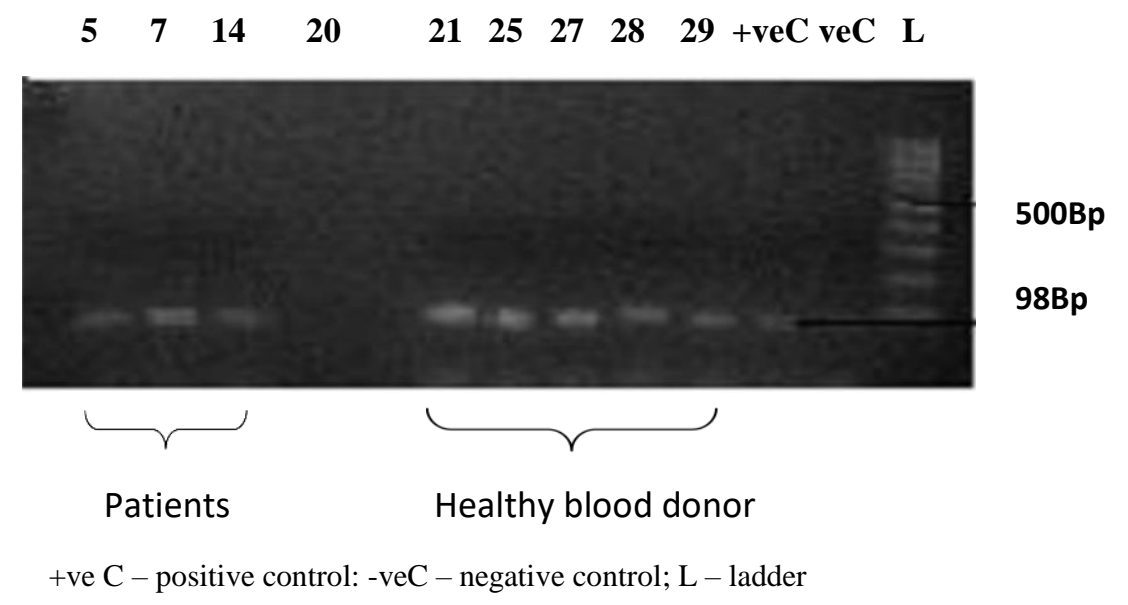

Figure 4: PCR confirmed PSUE gene in P. aeruginosa isolates. 


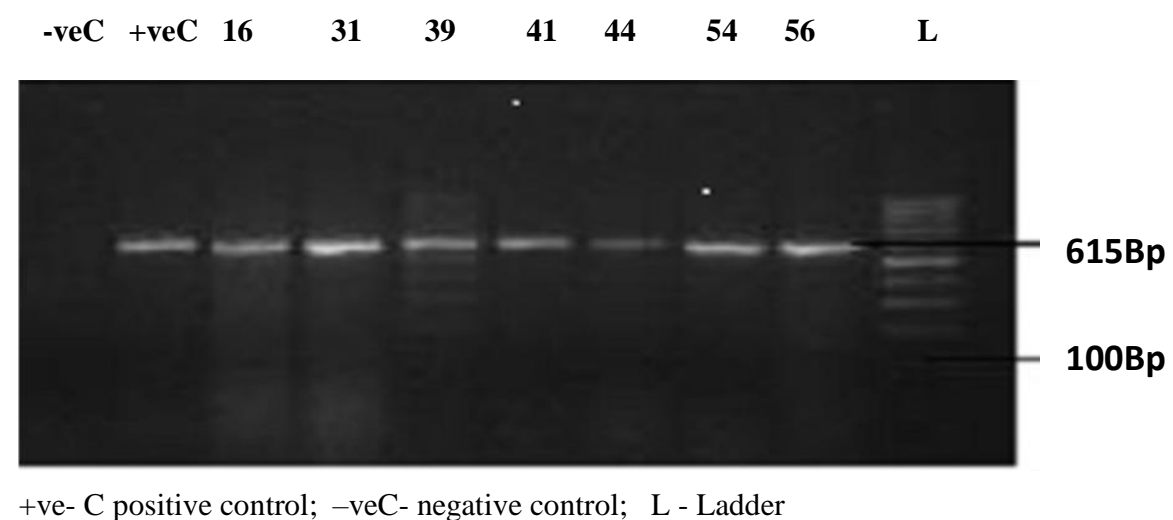

Figure 5: PCR confirmed Pf gene in Klebsiella pneumoniae isolates

\section{Discussion}

The severity of liver infection is likely to contribute to susceptibility to co-infection and bacterial infections can also contribute to the chronicity of disease in HBV patients. Bacterial infections are common in patients suffering with viral hepatitis and are critical for prognosis. ${ }^{14}$ Other studies also have confirmed the association between bacterial infections and HBV and also bacterial infections in cirrhotic patients as an important cause of morbidity and mortality. ${ }^{15}$

It is important to note that most of the patients in the current study were in their acute stage although liver function tests were not determined. In this study, the prevalence of bacterial infections in patients with HBsAg was determined as $45.1 \%$.

The organisms isolated were $P$. aeruginosa, E. coli, $K$. pneumoniae, and $S$. aureus. $P$. aeruginosa was isolated most often in both patients and blood donors in this study which was similar to a study conducted in Korea. ${ }^{16}$ Sample cultures with no bacterial growth were 67 (54.9\%) and Salmonella Typhi was not isolated in this study. $S$. aureus and E. coli were each isolated in $5.7 \%$ of the samples, in contrast with a similar study which reported $43.2 \%$ for $S$. aureus ${ }^{15}$ and $54.5 \%{ }^{12}$ for $E$. coli. K. pneumoniae reported in this study was $9.8 \%$, which was similar to a study conducted in China that reported approximately $20 \% .^{14}$

All K. pneumoniae isolates in the current study were resistant to ciprofloxacin as also reported by Alo et $\mathrm{al}^{17}$ and Cheong et al ${ }^{15}$ who reported $80 \%$ and $100 \%$ resistance respectively. It is notable that bacteraemia was significantly associated with the presence of biliary disease in cirrhotic patients and one of the most implicated bacteria was P.aeruginosa. ${ }^{17}$ In this study, P. aeruginosa demonstrated very high resistance to ciprofloxacin and ceftazidime similar to other studies. ${ }^{18}$ The ceftazidime resistance in this study was high (100\%), in agreement with $91 \%$ that was reported in Egypt. ${ }^{18}$ 
Antibiotic susceptibility of $E$. coli isolates in the current study were similar to those previously reported. Kibret et al reported E. coli resistant to ciprofloxacin $(79.6 \%)$ and gentamicin $(71.4 \%)$ in a study in Ethiopia. ${ }^{19}$ All E. coli isolates in the current study were resistant to ciprofloxacin, similar to the results of Cheong et al. ${ }^{15}$ Ciprofloxacin resistance of $S$. aureus in the current study was $100 \%$, similar to a study conducted in Korea which demonstrated very high resistance to ciprofloxacin and oxacillin. ${ }^{11}$

Of the E. coli isolated in the current study, $42.9 \%$ were ESBL producers. Similar results have been reported from Pakistan $(56.9 \%)^{20}$ and India $(40 \%) .{ }^{13}$

Of $K$. pneumoniae isolated in the current study, $25 \%$ were ESBL producers. A similar result (33\%) was obtained in a study in $\operatorname{Iran}^{21}$ in contrast to an African study which reported $71.7 \% .^{22}$

Of $P$. aeruginosa isolated in the current study, 24\%were ESBL producers. These results were similar to other studies which reported $22 \%{ }^{11}$ and $13.79 \%^{23}$ ESBL production. The ESBL producing $P$. aeruginosa isolates exhibited co-resistance against most of the antibiotics tested, consistent with results of other recent studies. ${ }^{8,18}$

The high incidence of ESBL producers among the isolates in the current study has considerable health implications as shown in recent studies, where infection with ESBL producing Gram negative bacilli resulted in significantly higher fatality rates than those with non-ESBL isolates. ${ }^{8}$

\section{Conclusion}

Bacteraemia with or without symptoms appear to occur in those demonstrated to be HBV positive. Further studies to follow up such patients and assess the significance of these bacteraemic episodes would be useful, particularly as a significant number of the isolated organisms showed antibiotic resistance to commonly used antibiotics.

\section{REFERENCE}

1. Griffiths EC. The nature and consequences of coinfection in humans. J. Infect.2014; 63:200-206. doi: http://dx.doi.org/10.1016/j.jinf.2011.06.005

2. Lass S. Generating super-shedders: co-infection increases bacterial load and egg production of a gastrointestinal helminth. J. R. Soc.Interface.2013; 10:20120588. doi: http://dx.doi.org/10.1098/rsif.2012.0588

3. Gonzalez SA, Keeffe EB. Risk assessment for hepatocellular carcinoma in chronic hepatitis B: scores and surveillance. International Journal of Clinical Practices 2012; 66:7-10. doi: http://dx.doi.org/10.1111/j.1742-1241.2011.02808

4. Takako I, Yasuhito T. Hepatitis B virus and its sexually transmitted infection - an update. Microbial Cell 2016; 3(9):420-437. doi:10.15698/mic2016.09.527

5. Zoulim F, Locarnini S. Optimal management of chronic hepatitis B patients with treatment failure and antiviral drug resistance. Liver International Supply 2013; 1:116-124 doi: .http://dx.doi.org/10.1111/liv.12069

6. Koutsoumpas AL, Smyk DS, Bogdanos DP. E. coliinduced experimental model of primary biliary cirrhosis: At last. International Journal of Hepatology 2014; 1-6. doi:http://dx.doi.org/10.1155/2014/848373 
7. Petri A, Tiszlavicz L, Nagy E. Liver abscess caused by Stenotrophomonas maltophilia: Report of a case. Surg Today 2003; 33(3):224-8. doi: http://dx.doi.org/10.1007/s005950300050

8. Yaita K. Liver abscess caused by multidrug-resistant Pseudomonas aeruginosa treated with colistin; a case report and review of the literature. International Medicine 2013; 52 (12):1407-1412. doi:http://dx.doi.org/10.2169/internalmedicine.52.9296

9. Lin D, Koskella B. (2014). Friend and foe: factors influencing the movement of the bacterium Helicobacter pylori along the parasitism-mutualism continuum. Evol. Appl.2014; 8:9-22. doi: http://dx.doi.org/10.1111/eva.12231

10. Reddy PN, Srirama K, Dirisala VR. An Update on Clinical Burden, Diagnostic Tools, and Therapeutic Options of Staphylococcus aureus. Infect Dis (Auckl) 2017; 10: doi: 10.1177/1179916117703999

11. Park JK, Lee CJ, Kim IH, et al. Clinical Characteristics and Prognostic Impact of Bacterial Infection in Hospitalized Patients with Alcoholic Liver Disease. J Korean Med Sci. 2015; 30 (5):598-605. doi:https://doi.org/10.3346/jkms.2015.30.5.598

12. CLSI (Clinical and Laboratory Standard Institute). Performance Standards for Antimicrobial Disc Susceptibility Tests; Approved Standard-Eleventh Edition. CLSI document M02-A11, Wayne, PA, USA., 2012.

13. Kumar D, Singh AK, Ali MR, et al. Antimicrobial Susceptibility Profile of Extended Spectrum $\beta$ Lactamase (ESBL) Producing Escherichia coli from Various Clinical Samples. Infect Dis (Auckl) 2014; 7: 1-8. doi: 10.4137/IDRT.S13820

14. Wei Li, RonghuaJin, Peng Chen, Guoxian Zhao, Ning Li \&Hao W Clinical correlation between HBV infection and concomitant bacterial infections. Sci. Rep 2015; 5, 15413; doi: https://doi: 10.1038/srep15413

15. Cheong HS, Kang CI, Lee JA. Clinical significance and outcome of nosocomial acquisition of spontaneous bacterial peritonitis in patients with liver cirrhosis. Clin Infect Dis2014; 48:1230-1236. doi:https://doi.org/10.1086/597585

16. Tian LT, Yao K, Zhang XY, et al. Liver abscesses in adult patients with and without diabetes mellitus: an analysis of the clinical characteristics, features of the causative pathogens, outcomes and predictors of fatality: a report based on a large population, retrospective study in China. Clin Microbiol Infect 2012; 18: E314-E330. doi: https://doi.org/10.1111/j.1469-0691.2012.03912

17. Alo MN, Anyim C, Igwe JC, et al. Presence of extended spectrum $\beta$-lactamase (ESBL) E. coli and $K$. pneumonia isolated from blood cultures of hospitalized patients. Advances in Applied Science Research 2012; 3(2):821-825 No doi

18. Mahmoud BA, Zahran WA, Hindawi GR, et al. Prevalence of multidrug-resistant Pseudomonas aeruginosa in patients with nosocomial infections at a University Hospital in Egypt, with special reference to typing Methods. Journal of Virology \&Microbiology Vol. 2013, 1-13.

doi: https//doi.org/ 10.5171/2013.29004

19. Kibret M, Abera B. Antimicrobial susceptibility patterns of $E$. coli from clinical sources in northeast Ethiopia. Afric Health Sci 2011; 11:S40-S45 No doi

20. Ullah F, Malik SA, Ahmed J. Antibiotic susceptibility pattern and ESBL prevalence in nosocomial Escherichia coli from urinary tract infections in Pakistan. Afr. J. Biotechnol 2009; 8(16):3921-3926 No doi

21. Ghafourian S, Sekawi ZB, Sadeghifard N, et al. The Prevalence of ESBLs Producing Klebsiella pneumoniae Isolates in Some Major Hospitals, Iran. Open Microbiol J 2011; 5: 91-95. doi: 10.2174/1874285801105010091

22. Ejaz I, Aizza Z, SaqibM, et al. Urinary tract infections caused by extended spectrum $\beta$-lactamase (ESBL) producing Escherichia coli and Klebsiella pneumonia. African Journal of Biotechnology 2011; 10(73):16661-16666, doi: 10.5897/AJB11.2449 ISSN 1684-5315 @ Academic Journals

23. Shaikh S, Fatima J, Shakil S, et al. Antibiotic resistance and extended spectrum beta-lactamases: Types, epidemiology and Treatment. Saudi Journal of Biological Sciences 2015; 22:90-101. doi:https://doi.org/10.1016/j.sjbs.2014.08.002 